\title{
Health Risk Assessment and Seasonal Trend of Metals in Arid-Soil-Forage Crops and Animals
}

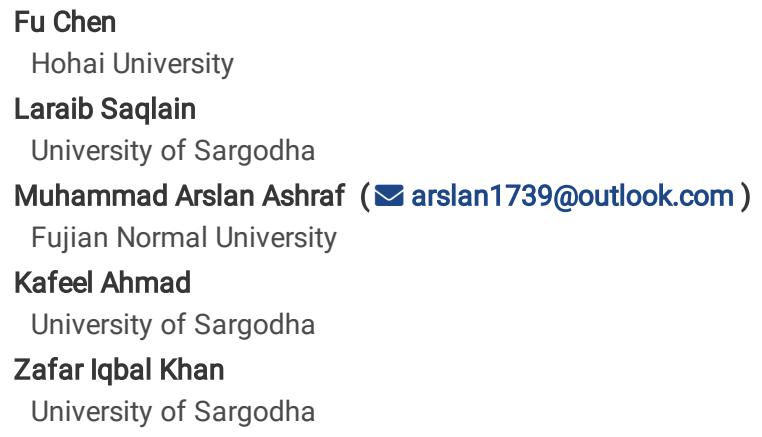




\section{Abstract}

Background: The aim of study was accessing the cobalt $(\mathrm{Co})$ and lead $(\mathrm{Pb})$ contamination in soil, forages and animals. The heavy metal ions bioaccumulation and escalating transfer to food chain has become main concern for mankind. Nevertheless, they play crucial role in organismal metabolism, however exceeding threshold level causes toxicity or even system failure. Since the plants are the main source of nutrition supply and carbohydrates for animal metabolism, therefore mankind exposure risk to food chain heavy metal toxicity increases significantly.

Method: To highlight toxicity levels and exposure risk we designed this field study in the nearby areas of district Mianwali, Punjab, Pakistan during different seasons._and carried out samplings of soil, native flora. While following research ethics we collected samples of blood, hair and feces from domestic herbivore animals. Traditional wet digestion was carried out in available laboratory facilities, $\mathrm{Pb}$ and Co heavy metal concentrations were analyzed with atomic absorption spectrum. With emphasis on health risk index (HRI) and bio-concentration factor (BCF), we also draw attention to pollution load index (PLI), daily intake of metal (DIM), Health Risk Index (HRI) and Enrichment factor (EF).

Results: Our findings revealed high Pb concentration $(5.29-9.84 \mathrm{mg} / \mathrm{kg}$ ) in forage during season 1 . While our findings indicate concentrations of metal in different seasons. When the Co concentration in forages was 0.238 to $0.492 \mathrm{mg} / \mathrm{kg}$ and $\mathrm{Pb}$ was found in the range of $5.29-9.84 \mathrm{mg} / \mathrm{kg}$ ). Soil samples showed higher level of (PLI) Pollution load index. Bio-concentration of cobalt and lead was (0.447- 1.106 and $0.717-1.152 \mathrm{mg} / \mathrm{kg})$ respectively.

Conclusions: Bio-concentration factor and pollution load index for Co and Pb was noticed significantly higher than 1. Whereas enrichment factor (EF) was under permissible limit for both metals, daily intake metal (DIM) and no harmful health risk concentration was found. Therefore, wide-scale regular monitoring for heavy metal risk assessment on seasonal basis are highly recommended to avoid or minimize further contamination.

\section{Introduction}

Extreme toxicity for the metal is due to reason that, dissimilar to organic matter, trace metals are not biodegradable although they merely alter their oxidation state as well as they are very exceedingly persistent in environment having a half-life greater than twenty years (Hadia-e-Fatima et al., 2018). recognized elements are termed as heavy metals and they are characterizing as universal pollutants having densities were greater than 5 gram per centimeter cube (Ashraf et al., 2019; Prieto et al., 2018). In the soil ecosystem heavy metal elements are components of soil. Accumulation of metal in soil and getting mixed with the groundwater is perhaps damaging to livestock, forages and other plants.

In soil heavy metals are present in combined state and are soluble with water. Some heavy metals occur in soil having soluble state of water. These metals are mobile because they are chelated with other metal and metalloids hence, they are easily available to forage plants. Heavy metals are incorporated into food chain in a direct pathway when these trace metals are accumulated in forages because forages absorb trace metals from water, air and soil (Chiroma et al., 2014).

Contaminants consisted of toxic consequences of organism's corpse by producing digestion related issues, malfunctioning of excretive system, immune system disorders, respiratory diseases, and glandular failure. Chronic disorders, lethal cancerous tumours, psychological illnesses, reducing growth and development and psychological illnesses are furthermore linked with toxicosis (Unver et al., 2015).

Forages species that are grown on contaminated soil become more contaminated by the heavy metals (Nadeem et al., 2019). Pasturage grown along boundaries of highways are promptly influenced by heavy metals stress by liberation of unhealthy smoke, these hazardous conditions have more dangerous impacts on forages as compared to others (Dogan et al., 2014a,b). Heavy metals enter food chain firstly they are accumulated into forage plant body and soil; through forage consumption heavy metals enter the body of livestock (Khan et al., 2018).

Cobalt is a trace metal in forages shown by its normal concentration level, its normal concentration found in their dry weight is almost $0.1-10 \mu g g^{-1}$. Many enzymes and coenzymes contain cobalt as their significant constituents. Physiological conditions of forages and their growth is altered by the amount of Co (cobalt) occurring in rhizosphere and soil. It commonly from complexes while interacting with other metals. Seasonal changes have influenced the bioavailability of heavy metals and mature growth and developments of forages (Kalaivanan et al., 2016).

Metabolic pathways of forage plants are directly affected by lead $(\mathrm{Pb})$ accumulation in forages; although, it produces deficiencies of other metals, lead $(\mathrm{Pb})$ is also responsible of damage to plant cells when its level is above permissible limits and cause toxicity (Bibi et al., 2014). When Pb level is less than permissible limits in the soil of an area this is not harmful for grazing ruminants and forage species. If canal water is used for irrigation purpose instead of industrial effluent water and sewage water, the Pb concentration is less in these plants, so the forages less hazardous for the grazing animals. Anthropogenic activities increase the lead $(\mathrm{Pb})$ contamination above the permissible limits and change the extrinsic and intrinsic factors of pasture soil (Shad et al., 2014). This study aims to investigate the concentrations of lead (Pb) and Cobalt (Co) in soil, forage crops and animals. Current study was designed with following objectives; seasonal variations among bioconcentration, pollution load indices and daily intake metals for heavy metals concentrations.

\section{Materials And Methods}

\subsection{Study Area:}

District Mianwali is in south-western region of province Punjab. This district has plains of western area of salt range. It is situated near the Sakesar hill. Mianwali district has boundaries with Khushab, D.I Khan, Bhakkar and Bannu districts. Canal irrigation system is very less developed, only a little area is 
irrigated with Indus river irrigation system. The native of this district is affiliated with bordering plant resources. District Mianwali is divided into three Tehsils such as Piplan, Mianwali and Esakhel. Mianwali city is the larger city. Its human population is about 140000. One of the popular areas is Kalabagh, brown salt hills, Kalabagh Dam, Indus river and Nawab of Kalabagh. At the south side of district tehsil Piplan is situated and towads north-west tehsil Esakhel is located. These areas are economic and commercial zones of the district (Ghani et al., 2016; Qureshi et al., 2007).

\subsection{Sample collection from sites}

In district Mianwali four sites were selected for sampling. Three samples of agricultural soil, forages and animal blood, hair and feces were taken to examine the metal profile of soil-forage-animal continuum. The samples were taken from Wan bhachran site, Mianwali, Esakhel and Piplan. The summer, autumn and winter seasons were selected for sampling. The samples were taken randomly from sites.

\subsection{Soil sample collection}

In the district Mianwali four sites were selected to collect the samples. 3 samples of soil were collected with equal distances in the field. Stainless steel auger was used to dig up the upper layer of soil about 12-15 cm (Siddique et al., 2019). These samples were packed into plastic bags to avoid the mixing of other chemical compounds into it. Samples were stored in laboratory and labeled then metal analysis was performed. For each sample three composite samples were made. The collected samples were firstly air then oven drying at $72^{\circ} \mathrm{C}$ for 2 days. The samples were placed in incubators at $70^{\circ} \mathrm{C}$ temperature for 5 days.

\subsection{Forage sample collection}

Sterilized apparatus was used to collect the forage samples. Forage and soil were collected from same field and place. Only those forages were selected for taking samples that are used as common feed of livestock. 3 samples of each forage plant were taken from the sampling area. The samples were washed with distilled water to clear impurities and dirt. These samples were dried to eliminate moisture in the freshly collected samples. The collected samples were dried for further process.

These are following species that were selected for sampling. Calotropis procera (Apocynaceae), Dactyloctenium aegyptium (Poaceae), Parthenium hysterophorus (Asteraceae), Rumex dentatus (Polygonaceae) and Ziziphus jujube (Rhamnaceae).

\subsection{Animal blood plasma, hair and feces sample collection}

Blood samples of cow, buffalo and sheep of Mianwali was taken in 2020. Young animals within age of two years were selected for sampling. Blood was collected from four sites of district Mianwali. Animal blood was calculated from 10 animals (Cow, buffalo and sheep) each from each sampling site and heavy metal evaluation was done. Sterilized syringe was used to obtain the blood samples. The grazing ruminant's blood was taken from the vein. The vacuum was created in evacuated tubes while collecting blood to minimize the extent of clotting. The blood was collected in heparinized Na-citrate voiles quickly. For 15 minutes blood was centrifuged at $3000 \mathrm{rpm}$ and blood plasma was separated. Polyethylene tubes were used to store the blood plasma and frozen at $-20^{\circ} \mathrm{C}$. Hair and feces samples were also collected and stored for the further digestion process.

\subsection{Sample measurement and preparation}

Arrangement and preparation of samples involves the digestion process. This method of digestion is called wet digestion. It has following steps. Acid and hydrogen per oxide is used for complete digestion process. Distilled water is added after digestion into prepared samples for dilution purpose. After that filtration of samples occur. In next step Atomic Absorption Spectrophotometer (AAS) is an apparatus through which metal analysis is done.

\subsection{Apparatus and chemicals for digestion}

Chemicals that are used for digestion process includes the $10 \mathrm{ml}$ Nitric acid ,70\% Sulphuric acid $\left(\mathrm{H}_{2} \mathrm{SO}_{4}\right), 50 \%$ Hydrogen peroxide $\left(\mathrm{H}_{2} \mathrm{O}_{2}\right)$ and newly synthesized condensed water or distilled $\left(\mathrm{H}_{2} \mathrm{O}\right)$. The apparatus for digestion includes digestion flasks of $100 \mathrm{ml}$, measuring cylinder $(50 \mathrm{ml})$, beakers $(50 \mathrm{ml})$ and $(100 \mathrm{ml})$, pipette $(10 \mathrm{ml})$, filter paper, stirrer, hotplate and gloves.

\subsection{Digestion of soil, forages and Animal samples}

Digestion of soil and forages and animal samples (blood, hair and faeces) include various steps. First, the samples are air dried and followed by oven dried process at $72^{\circ} \mathrm{C}$ for 5 days until the moisture content is removed. When plants are completely dried, they weighed with electrical balance. Standard procedure of digestion was applied to digest the samples (Siddique et al. 2019). 1gm sample was weighed by electrical balance and placed in a beaker of $50 \mathrm{ml}$. A $10 \mathrm{ml}$ nitric acid was added to beaker and was kept overnight. Hot plate was used for digestion of sample by pouring $\mathrm{H}_{2} \mathrm{O}_{2}$ drop wise until solution becomes transparent. Cooling at room temperature was done. For dilution $50 \mathrm{ml}$ distilled water added to solution. To filter the solution Whatman filter paper of $42 \mu \mathrm{m}$ was used. Then this prepared solution was kept in plastic bottles for metal profile evaluation.

Blood samples collected from the Mianwali district were stored and freeze at $-20^{\circ} \mathrm{C}$. For digestion process the samples were from freezer and digested with same standard procedure as applied to soil and forages (Siddique et al., 2019). Hair sample was sun dried and was cut into pieces of 1.0-2.9 cm. Deionized water was used to wash the samples and ethanol was also applied to wash. Oven drying process was carried out and for 4 hours and then desiccator cooling was performed (Hashem et al., 2017). Feces samples were collected from cow, buffalo and sheep after air drying and oven dry the samples were submitted for digestion (Nicholson et al.1999). 


\subsection{Metal profile evaluation analysis}

The prepared samples were then analyzed for metal contents by Atomic Absorption Spectrophotometer (Perkin-Elmer Corp, 1980). Nutritional minerals that were evaluated in the sample were $\mathrm{Co}$ and $\mathrm{Pb}$. Standard solution was prepared to get the standardized curve. The metal analysis was done by running the samples through Atomic Absorption Spectrophotometer. This apparatus is equipped with a graphite furnace. Each metal is measured according to value of standard solution. The amount of each metal occurring in the sample is obtained in absolute farm. While sample is run through the Atomic Absorption Spectrophotometer the little quantity of sample is sprayed at the flame. Atomic resonance absorption line by element is calculated and measured. The apparatus is convenient for analysis. Any radiation that is emitted by flame had no effect on the working of apparatus. The absorption method is independent of the excitation potential of the spectral line used.

\subsection{Evaluation Indices:}

\subsubsection{Bio concentration Factor (BCF):}

For assessment of metal ( $\mathrm{mg} / \mathrm{kg}$ ) transport from agricultural soil and forages that are growing on this soil, a BCF is applied (Cui et al., 2004).

BCF for soil to forage

$(B C F)=$ Level of metal in forage / Level of metal in soil

\subsubsection{Pollution load index (PLI)}

Liu et al. (2005) described a formula which was used to find these indices.

$$
\text { Pollution load index }=\frac{(M) I S}{(M) R S}
$$

Whereas,

(M) IS = $(\mathrm{mg} / \mathrm{kg})$ Concentration of metal that occurs in soil to investigate

(M)RS= Soil reference value of metal (Table 1).

\subsubsection{Enrichment factor (EF)}

Formula for Enrichment factor is described by Buat-Menard and Chesselet (1979). See the Table 2.

$$
\text { Enrichment factor }(E F)=\frac{\frac{\text { Conc.of metal in plant }}{\text { Conc. of metal in soil (Sample) }}}{\frac{\text { Conc.of metal in plant }}{\text { Conc.of metal in soll (Standard) }} C}
$$

\subsubsection{Daily intake of metals (DIM)}

Daily intake of metal (DIM) can be calculated by following equation from Sajjad et al. (2009).

$$
D I M=\frac{C_{\text {factor }} \times C_{\text {metal }} \times D_{\text {food intake }}}{B_{\text {average weight }}}
$$

Whereas,

$C_{\text {metal }}$ is the concentration of metals in forages,

$D_{\text {food intake }}$ is the daily intake of forages,

$B_{\text {average weight }}$ is the average body weight.

For calculating this daily intake of metal, the conversion factor was taken 0.085 (Jan et al., 2010). Daily intake metal for cow was calculated by using animal body weight $600 \mathrm{~kg}$ and daily forage intake $12 \mathrm{~kg}$ while for sheep body weight was taken $75 \mathrm{~kg}$ and daily forage intake $1.3 \mathrm{~kg}$ (Johnsen and Aaneby, 2019). To calculate the DIM for buffalo body weight was taken $550 \mathrm{~kg}$ and daily forage intake (TDI) was taken 12.5 kg (Yang et al., 2020$)$.

\section{Health Risk Index (HRI)}

Health risk index is the ratio of daily intake of metals in the forages to oral reference dose (RfD) and was calculated by the help formula (USEPA, 2002). 
Health risk index $(H R I)=\frac{D I M}{R_{f} D}$

DIM = Daily intake of heavy metal

$\mathrm{R}_{\mathrm{f}} \mathrm{D}=$ Oral reference dose (Table 3$)$

An HRI > 1.0 for any single metal indicates that the health of consumer population is at risk, or it is carcinogenic (USEPA, 2013).

\section{Results}

\section{Concentration of Cobalt in soil}

The variation of Co metal concentration ranged from minimum $0.420 \mathrm{mg} / \mathrm{kg}$ and maximum $0.532 \mathrm{mg} / \mathrm{kg}$. The minimum value of Co in soil was observed in Z. jujube during S_3. The maximum value was noticed in the samples collected in S_3 (Fig 2). The permissible range of UNEP (2013) for Co metal is 100 $\mathrm{mg} / \mathrm{kg}$. The calculated amount of Co is less than permissible limit in our samples (Table 4 and Table 12).

\section{Concentration of Cobalt in forage}

The analysis of Co metal in forage sample had different concentration in different forages. The mean concentration for Co ranged from $0.238 \mathrm{mg} / \mathrm{kg}$ minimum to $0.492 \mathrm{mg} / \mathrm{kg}$ maximum. The minimum value was noticed in $C$. procera during S3 (Fig 3 ). The maximum amount was exhibited by 0.492 $\mathrm{mg} / \mathrm{kg}$ during period of S1 in Z. jujube forage (Table 5 and Table 13). Our present calculated values for cobalt in forages were lower than permissible limits of $52 \mathrm{mg} / \mathrm{kg}$ by WHO (2001).

\section{Concentration of Cobalt in animals}

The blood had the values Co ranging from lower amount to higher amount $(0.389-0.536 \mathrm{mg} / \mathrm{l})$. The higher concentrations were observed in sheep during season S_2 and lower concentration during S3 in buffalo. The presence of Co blood was noticed similar with the $0.5 \mathrm{mg} / \mathrm{l}$ as compared to the values given by Schweinzer et al. (2017). The hair had Co concentration ranging from (0.377- $0.537 \mathrm{mg} / \mathrm{kg})$ the maximum concentration of Co was present cow of S_1 while the minimum concentration of Co was noticed in sheep of S_3 (Table 6 and Table 14). The Co value in feces ranged the minimum to maximum $(0.383-0.518 \mathrm{mg} / \mathrm{kg})$ the higher amount of Co was found in cow during S_2 and lower value was noticed in sheep during S3 (Fig 1).

\section{Bio-concentration Factor (BCF) of Cobalt}

The Bio-concentration factor of Co was ranged from 0.447 to $1.106 \mathrm{mg} / \mathrm{kg}$. The lowest concentration was noticed in $C$. procera in S3. The maximum amount for BCF was noticed in Z. jujube in S1 (Table 7).

\section{Pollution Load Index (PLI) of Cobalt}

The pollution load index (PLI) was found within the range between $0.072 \mathrm{mg} / \mathrm{kg}-0.102 \mathrm{mg} / \mathrm{kg}$. The low concentration was observed in $C$. procera during S1 (Table 8).

\section{Enrichment Factor (EF) of Cobalt}

The enrichment factor for Co metal was noticed in range between $0.081 \mathrm{mg} / \mathrm{kg}-0.172 \mathrm{mg} / \mathrm{kg}$. The minimum concentration was noticed in $C$. procera during S3. The maximum amount was found C. procera during S1 (Table 9).

\section{Daily intake of metal (DIM) of Cobalt}

The daily intake of metal (DIM) for Co ranged from $0.00035-0.00095 \mathrm{mg} / \mathrm{kg}$. The lower level was found in sheep during S3 while the higher concentration was noticed in buffalo in S1 (Table 10).

\section{Health Risk Index (HRI) of Cobalt}

The health risk index for Co ranged from $0.008 \mathrm{mg} / \mathrm{kg}-0.022 \mathrm{mg} / \mathrm{kg}$. The minimum values were noticed in $P$. hysterophorus during S3 while the higher amount was found in Z. jujube in S1 (Table 11).

\section{Concentration of Lead in Soil}

The $\mathrm{Pb}$ concentration in soil samples had different amounts in each sample of soil. The amount of $\mathrm{Pb}$ varied in the range from minimum $6.60 \mathrm{mg} / \mathrm{kg}$ to maximum $10.89 \mathrm{mg} / \mathrm{kg}$ (Table 12 and 4). The maximum concentration of soil was exhibited by soil of forage $R$. dentatus during S3 and minimum concentrations was observed in soil of forage $R$. dentatus during S1(Fig 2). The permissible limit of Pb in UNEP (2013) is 200 mg/kg the evaluated value of $\mathrm{Pb}$ in soil samples is lower than the permissible values.

\section{Concentration of Lead in forage}


The analysis of variance for $\mathrm{Pb}$ showed the significant effect in season. It showed the non-significant effect in soil and Season $\times$ soil (Table 5). The amount of $\mathrm{Pb}$ in different samples was different in each forage samples. The minimum amount of $\mathrm{Pb}$ was noticed $5.29 \mathrm{mg} / \mathrm{kg}$ in $P$. hysterophorus during $\mathrm{S} 1$ (Table 13). The maximum value of $\mathrm{Pb}$ was present in $9.84 \mathrm{mg} / \mathrm{kg}$ in $R$. dentatus during S3 (Fig 3). The Pb concentration was found within the permissible limits of $10 \mathrm{mg} / \mathrm{kg}$ as given by (WHO, 1995).

\section{Concentration of Lead in animals}

The analysis of variance for $\mathrm{Pb}$ showed the significant effect in Season. The non-significant effect was shown by Animal, Source, Season $\times$ Animal, Season $\times$ Source, Animal $\times$ Source and Season $\times$ Animal $\times$ Source (Table 6). The Pb concentration in blood ranged from minimum to maximum (1.01-2.44 $\mathrm{mg} / \mathrm{l})$. The minimum value was noticed in sheep during S1and maximum value was noticed in buffalo during S3 (Table 14). This current investigation for $\mathrm{Pb}$ in blood was greater as compared to $0.2 \mathrm{mg} / \mathrm{l}$ by Puls (1988). The hair had Pb value ranged from lower to higher (1.00-2.33 mg/kg). The maximum value of $\mathrm{Pb}$ in hair was noticed in cow during S3 and minimum value was found in buffalo in $\mathrm{S} 1$ (Fig 1). The Pb in animal feces varied in the range from minimum to maximum $(0.63-2.22 \mathrm{mg} / \mathrm{kg})$. The minimum value was observed in cow during $\mathrm{S} 1$ and maximum value was noticed in sheep of $\mathrm{S} 2$.

\section{Bio-concentration Factor (BCF) of Lead}

The bio-concentration for $\mathrm{Pb}$ was ranged from $0.717-1.152 \mathrm{mg} / \mathrm{kg}$. The minimum amount was found in $P$. hysterophorus during $\mathrm{S} 1 \mathrm{while}$ the maximum amount was depicted by $D$. aegyptium in S3 (Table 7).

\section{Pollution Load Index (PLI) of Lead}

The $\mathrm{Pb}$ pollution load index was found similar within the range from $0.809-1.048 \mathrm{mg} / \mathrm{kg}$. The minimum amount was exhibited by the $R$. dentatus in the $\mathrm{S} 1$ while the maximum value was depicted by $C$. procera during S3 (Table 8 ).

\section{Enrichment Factor (EF) of Lead}

The enrichment factor $\mathrm{Pb}$ was noticed within the ranged from 1.95- $3.129 \mathrm{mg} / \mathrm{kg}$. The lowest value was noticed in $\mathrm{S} 1$ while the highest value was found in S3 (Table 9).

\section{Daily intake metal (DIM) of Lead}

The daily intake metal (DIM) was ranged in Pb from 0.0190-0.0078 mg/kg. The minimum value was observed in S1 and was noticed in sheep while the maximum concentration was found in buffalo during S3 (Table 10).

\section{Health Risk Index (HRI) of Lead}

The health risk index for $\mathrm{Pb}$ varied within range from $1.95-4.75 \mathrm{mg} / \mathrm{kg}$. The minimum concentration was noticed from sheep during $\mathrm{S} 1 \mathrm{while}$ the highest level was found in the buffalo in S3 (Table 11).

\section{Discussion}

Present Co concentration in soil was recorded lower than permissible limits $10 \mathrm{mg} / \mathrm{kg}$ given by WHO (2000). This current study for Co in soil was in accordance with the investigations given by Tahir et al., (2017). Our result for soil Co concentration was below as compared to the findings of Uren (2013). Nature of soil properties are responsible for occurrence of Co in soil moreover there are other factors that are too responsible for cobalt in soil such as interface of soil-forage root, mechanism of property and pedo-geochemical effects (Lange et al., 2014). The Pb in soil samples was observed lower than that of the values given by Angelova et al. (2010). Pb amount in present findings was greater as compared to the values given by Nica et al. (2012). The current investigation for $\mathrm{Pb}$ in soil was lower as compared to narrated concentrations by Boussen et al. (2013). Our present work Pb level in soil was calculated higher than those given by Salazar et al. (2012). Pb in soil is accumulated due to presence of oxides and hydroxides of elements, minerals occurring in clay and organic matter dissolved in soil. Change in $\mathrm{pH}$ promotes lead precipitation in soil in form of carbonates, phosphates and hydroxides etc. When $\mathrm{Pb}^{2+}$ ion form compounds with humic compounds these are less available to forage (Wuana and Okieimen, 2011). Chelating agents are also involved in increasing or decreasing $\mathrm{Pb}$ availability in soil and transfer into forage plants (Butcher, 2009).

These results for Co in forages were observed below than the investigation given by Tahir et al., (2017). Our investigation for Co in forages was noticed greater than values given by Comino et al. (2011). The Co concentration forages was similar with the observations given by Liu et al. (2020). There are many interspecific and interspecific factors in cadmium uptake by forages. Sometime surface of plant is also contaminated with metal rich soil so there is chance to transfer metal in samples so precautious measures should be taken. Some phenotypic variations are also responsible for different concentration of forage plants (Faucon et al., 2007; Van der Ent et al., 2013). The amount of $\mathrm{Pb}$ in forages was found similar with the concentration of $\mathrm{Pb}$ given by Angelova et al. (2010). In this present work the $\mathrm{Pb}$ level in forage was in high range than the values given by Popovic et al. (2010). This value for $\mathrm{Pb}$ in forages was found lower as compared to the investigations by Salazar et al. (2012). In this study the present work was found lower than the Pb level estimated in forges by Cui et al. (2018). Pb is accumulated in forges near endodermis, it enters in forages through root via apoplast pathway and crosses cortex in radial manner. $\mathrm{Pb}$ is translocated from root to shoot in forages and endodermis acts as partial barrier. So, $\mathrm{Pb}$ is accumulated in roots in higher concentrations and less shoot of forages Sharma and Dubey (2005). 
This concentration of Co in blood was found in accordance with the results given by Ismael et al. (2015). The cobalt (Co) level in hair of ruminants was greater as compared to observations given by Hejna et al. (2018). This present study for Co-occurrence in sheep feces was lower than recordings of Abrahams (2013). Our work for Co amount in sheep blood was lower than the investigations by Tarhan et al. (2016). The value of Co in blood of cow was found similar with the findings by Abdel-Salam et al. (2013). The soil hydrogen ion concentration is responsible for Co transfer from soil-forage-animals. The lesser concentration of hydrogen ion is less effective and greater concentration is more effective in transfer of cobalt from soil to forages and forage to grazing ruminants (Čelechovská et al., 2008). The current study for Pb in livestock blood was found lower than depicted results by Ogundiran et al. (2012). Our Pb amount in cow blood was found greater as compared to the results given by Luna et al. (2019). This result for Pb in animal faeces was found lower as compared to the work of Ogundiran et al. (2012). Our findings for Pb in animal hair were observed higher as compared to the results given by Patra et al. (2017). Our findings for animal blood were found like the narrated value by Swarup et al. (2007). Human activities produce stress to environment and increase lead to the environment. The lead containing fodder is consumed by animal and lead accumulation takes place in the animal body parts (Abdel-Salam et al., 2013).

Safari et al. (2018) reported the similar results with the BCF of Co in current study. In these current findings our values were greater than Lotfy and Mostafa (2014). In our present recordings was observed lower as compared to the Kosiorek and Wyszkowski (2019). The value for Pb bio-concentration was observed similar with the values given by Nawab et al. (2015). Our work was found higher than the values given by the Sakizadeh et al. (2016). The present findings were found greater than the values narrated by Yang et al. (2014).

Our work for PLI cobalt (Co) was found similar as compared to investigations of Chandrasekaran et al. (2015). The current study was greater than recorded values given by Sulaiman et al. (2019). Present findings were investigated lower for PLI as compared to values given by Pathak et al. (2015). The PLI of Pb in this study was noticed lower than the values (PLI>2) investigated by Nawab et al. (2015). Our recorded values of PLI lead were found in accordance with observations by Zhuang et al. (2020). These current study Pb pollution load index was found greater than the narrated values of Barakat et al. (2012).

The current recordings for Co metal for (EF) were lower than the values given by Abbaslou et al. (2014). In present finding of Co was observed greater as compared to the values given by Giridhar and Samireddypalle (2015). This finding for Co enrichment factor was similar with the values given by Jing et al. (2019). The enrichment factor (EF) of Pb was ranged in this trend from higher to lower 1.95-3.129 mg/kg. Barakat et al. (2012) gave the greater values as compared to our work for $\mathrm{Pb}$ enrichment factor. Our present recordings were found greater than the findings by Marrugo-Negrete et al. (2017). Enuneku et al. (2017) likely found our calculated $\mathrm{Pb}$ enrichment factor.

Our daily metal intake metal for Co was lower than daily intake of metal observed by Ismail et al. (2015). These current investigations for Co (DIM) were similar with results given by Iwegbue (2010). In current study HRI for Co was in accordance with the concentrations recorded by Simonsen et al.

(2012). Present findings for health risk index (Co) were similar with recorded values by Khan et al. (2019). Our work for (DIM) Pb was lower as compared to the values recorded by Smith et al. (2010). The similar value of Pb daily metal intake was found in accordance with the observations by Nadeem et al. (2020). This present work for Pb health risk index was recorded greater than HRI calculated by Nadeem et al. (2020). In this finding the health risk index (HRI) Pb was observed higher than the values by Ugulu et al. (2020).

\section{Conclusion}

It was concluded that seasonal changes gave different fluctuating concentrations of metals and sites also gave fluctuating metal readings in soil-forageanimal continuum. In soil and forage samples collected from semi-arid environment $\mathrm{Co}$ and $\mathrm{Pb}$ was found toxic according to $\mathrm{FAO} / \mathrm{WHO}$. In animal samples $\mathrm{Pb}$ showed toxicity while the Co was found safe according to NRC standards. Bio-concentration factor and pollution load index for Co and Pb was noticed greater than 1. Enrichment factor was also in safe limits for all metals. Daily intake metal and health risk index was found less than 1.

\section{Declarations}

\section{Author contribution}

Fu Chen, Zafar lqbal Khan and Kafeel Ahmad supervised the study. Laraib Saqlain, collected samples, Muhammad Arslan Ashraf and Laraib Saqlain wrote first draft. Laraib Saqlain conducted experiment. Muhammad Arslan Ashraf participated in statistical data analysis. All authors equally contributed to discussion.

\section{Acknowledgements}

This work was supported by the National Natural Science Foundation of China (No.51974313) and the key project of Jiangsu Key Laboratory of Coalbased Greenhouse Gas Control and Utilization (2020ZDZZ03).

\section{Ethics declarations}

Conflict of interest: The authors declare that they have no conflict of interest.

Ethical approval: The authors declare that the manuscript has not been published previously.

Consent to participate: All authors voluntarily to participate in this research study. 
Consent to publish: All authors consent to the publication of the manuscript.

Availability of data and materials: All data generated or analyzed during this study are

included in this published article.

\section{Ethical Approval}

Institutional Human Ethics Committee of University of Sargodha (Approval No.25-A18 IEC UOS) has allowed all the protocols used in this experiment. to the commencement of the study. The authors declare 270 that manuscript has not been published previously.

\section{Funding:}

Not applicable

\section{References}

1. Abbaslou, H., Martin, F., Abtahi, A., Moore, F., 2014. Trace element concentrations and background values in the arid soils of Hormozgan Province of southern Iran. Archives of Agronomy and Soil Science 60, 1125-1143.

2. Abdel-Salam, N.M., Ahmed, S., Basir, A., Rais, A.K., Bibi, A., Ullah, R., Anwar, A.S., Zia, M., Hussain, I., 2013. Distribution of heavy metals in the liver, kidney, heart, pancreas and meat of cow, buffalo, goat, sheep and chicken from Kohat market Pakistan. Life Sci J 10, 937-40.

3. Abrahams, P.W., 2013.Geophagy and the involuntary ingestion of soil. In Essentials of medical geology.Springer, Dordrecht $433-454$.

4. Angelova, V.R., Ivanova, R.V., Todorov, J.M., Ivanov, K.I., 2010. Lead, cadmium, zinc, and copper bioavailability in the soil-plant-animal system in a polluted area. The Scientific World JOURNAL 10.

5. Ashraf, S., Alia, Q., Zahir, Z.A., Ashraf, S., Asghar, H.N., 2019. Phytoremediation: Environmentally sustainable way for reclamation of heavy metal polluted soils. Ecotoxicology and environmental safety 174, 714-727.

6. Barakat, A., El-Baghdadi, M., Rais, J., Nadem, S., 2012. Assessment of heavy metal in surface sediments of Day River at Beni-Mellal region, Morocco. Research Journal of Environmental and Earth Sciences 4, 797-806.

7. Bibi, Z., Khan, Z.I., Ahmad, K., Ashraf, M., Hussain, A., Nudrat, A.A., 2014. Vegetables as a potential source of metals and metalloids for human nutrition: a case study of Momordica charantia grown in soil irrigated with domestic sewage water in Sargodha, Pakistan. Pakistan Journal of Zoology 46.

8. Boussen, S., Soubrand, M., Bril, H., Ouerfelli, K., Abdeljaouad, S., 2013. Transfer of lead, zinc and cadmium from mine tailings to wheat (Triticum aestivum) in carbonated Mediterranean (Northern Tunisia) soils. Geoderma 192, 227-236.

9. Buat-Menard, P., Chesselet, R., 1979. Variable influence of atmospheric flux on the trace metal chemistry of oceanic suspended matter. Earth and Plan. Sci. Lett. 42, 398-411

10. Butcher, D.J. 2009. Phytoremediation of lead in soil: recent applications and prospects. Appl. Spectrosc. Rev. 44, $123-139$.

11. Čelechovská, O., Malota, L., Zima, S., 2008. Entry of heavy metals into food chains: a 20-year comparison study in northern Moravia (Czech Republic). Acta Veterinaria Brno 77, 645-652.

12. Chandrasekaran, A., Ravisankar, R., Harikrishnan, N., Satapathy, K.K., Prasad, M.V.R., Kanagasabapathy, K.V., 2015. Multivariate statistical analysis of heavy metal concentration in soils of Yelagiri Hills, Tamilnadu, India-Spectroscopical approach. Spectrochimica Acta Part A: Molecular and Biomolecular Spectroscopy 137, 589-600.

13. Chiroma, T.M., Ebewele, R.O., Hymore, F.K., 2014. Comparative assessment of heavy metal levels in soil, vegetables and urban grey wastewater used for irrigation in Yola and Kano. International refereed journal of engineering and science 3, 01-09.

14. Comino, E., Menegatti, S., Fiorucci, A., Schwitzguebel, J.P. 2011. Accumulation and translocation capacity of As, Co, Cr and Pb by forage plants. Agrochimica 55, 105-115.

15. Cui, T., Fang, L., Wang, M., Jiang, M., Shen, G., 2018. Intercropping of gramineous pasture ryegrass (Lolium perenne L.) and leguminous forage alfalfa (Medicago sativa L.) increases the resistance of plants to heavy metals. Journal of Chemistry.

16. Dogan, Y., Baslar, S., Ugulu, I., 2014b. A study on detecting heavy metal accumulation through biomonitoring: content of trace elements in plants at Mount Kazdagi in Turkey. Appl Ecol Environ Res 12, 627-636.

17. Dogan, Y., Unver, M.C., Ugulu, I., Calis, M., Durkan, N., 2014a. Heavy metal accumulation in the bark and leaves of Juglans regia planted in Artvin City, Turkey. Biotechnology \& Biotechnological Equipment 28, 643-649.

18. Enuneku, A., Biose, E., Ezemonye, L., 2017. Levels, distribution, characterization and ecological risk assessment of heavy metals in roadside soils and earthworms from urban high traffic areas in Benin metropolis, Southern Nigeria. Journal of environmental chemical engineering 5, $2773-2781$.

19. FAO/WHO .2001. Codex Alimentarius Commission. Food additive and contaminants. Joint FAO/WHO Food Standards Programme ALINORM 01/12A 1-289.

20. Faucon, M.P., Shutcha, M., Meerts, P., 2007. Revisiting copper and cobalt concentrations in supposed hyperaccumulators from SC Africa: influence of washing and metal concentrations in soil. Plant Soil 301, 29-36. 
21. Ghani, A., Nadeem, M., Ahmed, M.M., Hussain, M., Ikram, M., Imran, M., 2016. Spatial variations in nutritional and elemental profile of Mako (Solanum nigrum) collected from different tehsils of district Mianwali, Punjab, Pakistan. Sci. Int 5251-5255.

22. Giridhar, K., Samireddypalle, A., 2015. Impact of climate change on forage availability for livestock. In Climate change Impact on livestock: adaptation and mitigation. Springer, New Delhi 97-112.

23. Hadia-e-Fatima, A.A., 2018. Heavy metal pollution-A mini review. J Bacteriol Mycol Open Access 6, 179-181.

24. Hashem, M.A., Nur-A-Tomal, M.S., Mondal, N.R., Rahman, M.A. 2017. Hair burning and liming in tanneries is a source of pollution by arsenic, lead, zinc, manganese and iron. Environmental Chemistry Letters 15, 501-506.

25. Hejna, M., Gottardo, D., Baldi, A., Dell'Orto, V., Cheli, F., Zaninelli, M., Rossi, L., 2018. Nutritional ecology of heavy metals. Animal 12, $2156-2170$.

26. Ismael, M., El-Sayed, M.S., Metwally, A.M., Abdullaziz, I.A., 2015. Trace Elements Status and Antioxidants Profile in III-thrift Buffalo Calves. Alexandria Journal for Veterinary Sciences 44.

27. Iwegbue, C.M., 2010. Composition and daily intakes of some trace metals from canned beers in Nigeria. Journal of the Institute of Brewing 116 , 312315.

28. Jan, F.A., Ishaq, M., Khan, S., Ihsanullah, I., Ahmad, I., Shakirullah, M., 2010. A comparative study of human health risks via consumption of food crops grown on wastewater irrigated soil (Peshawar) and relatively clean water irrigated soil (lower Dir). Journal of hazardous materials 179, 612-621.

29. Jing, S., Jinyi, W., Xi, L., Jinhua, Q., Suyuan, D., Na, Y., 2019. Effects of Selenium and Cobalt on Germination of Alfalfa (Medicago sativa) at Different Temperatures. Animal Husbandry and Feed Science 11, 115-124.

30. Johnsen, I.V., Aaneby, J., 2019. Soil intake in ruminants grazing on heavy-metal contaminated shooting ranges. Science of the total environment 687 , 41-49.

31. Kalaivanan, D., Ganeshamurthy, A.N., 2016. Mechanisms of heavy metal toxicity in plants. In Abiotic stress physiology of horticultural crops. Springer, New Delhi. 85-102.

32. Khan, Z.I., Ugulu, I., Umar, S., Ahmad, K., Mehmood, N., Ashfaq, A., Bashir, H., Sohail, M., 2018. Potential toxic metal accumulation in soil, forage and blood plasma of buffaloes sampled from Jhang, Pakistan. Bulletin of environmental contamination and toxicology 101, $235-242$.

33. Kosiorek, M., Wyszkowski, M., 2019. Remediation of cobalt-polluted soil after application of selected substances and using oat (Avena sativa L.). Environmental Science and Pollution Research 26, 16762-16780.

34. Lange, B., Faucon, M.P., Meerts, P., Shutcha, M., Mahy, G., Pourret, O., 2014. Prediction of the edaphic factors influence upon the copper and cobalt accumulation in two metallophytes using copper and cobalt speciation in soils. Plant and soil 379, 275-287.

35. Liu, W., Ahmad, K., Khan, Z.I., Mughal, N., Wajid, K., Munir, M., Malik, I.S., Bashir, H., Mehmood, N., Muqadas, H., Noorka, I.R., 2020. Comparative study of forage toxic metals of conventional versus non-conventional pastures in relation to animal mineral nutrient allowance. Environmental Science and Pollution Research 27, 36579-36586.

36. Liu, W.H., Zhao, J.Z., Ouyang, Z.Y., Soderlund, L., Liu, G.H., 2005. Impacts of sewage irrigation on heavy metals distribution and contamination in Beijing, China. Environ. Int. 31, 805-812.

37. Lotfy, S.M., Mostafa, A.Z., 2014. Phytoremediation of contaminated soil with cobalt and chromium. Journal of Geochemical Exploration 144, 367-373.

38. Luna, D., López-Alonso, M., Cedeño, Y., Rigueira, L., Pereira, V., Miranda, M., 2019. Determination of Essential and Toxic Elements in Cattle Blood: Serum vs Plasma. Animals 9,465.

39. Marrugo-Negrete, J., Pinedo-Hernández, J., Díez, S., 2017. Assessment of heavy metal pollution, spatial distribution and origin in agricultural soils along the Sinú River Basin, Colombia. Environmental research 154, 380-388.

40. Nadeem, M., Khan, Z.I., Ghazal, M., Akhter, M., Akhter, P., Ahmad, K., Bashir, H., Noorka, I.R., Batool, A.I., Rehman, S., Ainee, A., Khan, I., 2020. Assessment of $\mathrm{Zn}$ and $\mathrm{Pb}$ in buffaloes fed on forages irrigated with wastewater in Sahiwal, Sargodha, Pakistan. Pure and Applied Biology (PAB) 9, 728-742.

41. Nadeem, M., Qureshi, T.M., Ugulu, I., Riaz, M.N., An, Q.U., Khan, Z.I., Ashfaq, A., Bashir, H., Dogan, Y., 2019. Mineral, vitamin and phenolic contents and sugar profiles of some prominent date palm (Phoenix dactylifera) varieties of Pakistan. Pak J Bot 51, 171-178.

42. Nawab, J., Khan, S., Shah, M.T., Qamar, Z., Din, I., Mahmood, Q., slamud, D., Mahmood, Q., Gul, N., Huang, Q., 2015. Contamination of soil, medicinal, and fodder plants with lead and cadmium present in mine-affected areas, Northern Pakistan. Environmental monitoring and assessment $187-605$.

43. Nica, D.V., Bura, M., Gergen, I., Harmanescu, M., Bordean, D.M., 2012. Bioaccumulative and conchological assessment of heavy metal transfer in a soilplant-snail food chain. Chemistry Central Journal 6, 55.

44. Nicholson, F.A., Chambers, B.J., Williams, J.R., Unwin, R.J., 1999. Heavy metal contents of livestock feeds and animal manures in England and Wales. Bioresource Technology 70, 23-31.

45. Ogundiran, M.B., Ogundele, D.T., Afolayan, P.G., Osibanjo, O., 2012. Heavy metals levels in forage grasses, leachate and lactating cows reared around lead slag dumpsites in Nigeria. International Journal of Environmental Research 6, 695-702.

46. Pathak, A.K., Kumar, R., Kumar, P., Yadav, S., 2015. Sources apportionment and spatio-temporal changes in metal pollution in surface and sub-surface soils of a mixed type of industrial area in India. Journal of Geochemical Exploration 159, 169-177.

47. Patra, R.C., Swarup, D., Naresh, R., Kumar, P., Nandi, D., Shekhar, P., Roy, S., Ali, S.L., 2007. Tail hair as an indicator of environmental exposure of cows to lead and cadmium in different industrial areas. Ecotoxicology and Environmental Safety 66, 127-131.

48. Popovic, D., Bozic, T., Stevanovic, J., Frontasyeva, M., Todorovic, D., Ajtic, J., Jokic, V.S., 2010. Concentration of trace elements in blood and feed of homebred animals in Southern Serbia. Environmental Science and Pollution Research 17, 1119-1128.

Page 9/16 
49. Prieto, M.J., Acevedo, S.O.A., Prieto, G.F., Nallely, T.G., 2018. Phytoremediation of soils contaminated with heavy metals. Biodiversity Int J 2, $362-376$. 50. Puls, R., 1988. Mineral levels in animal health diagnostic data. Published by Sherpa International, Clear brook, British Columbia, Canada. 17-152 51. Qureshi, R.A., Gilani, S.A., Ghufran, M.A., 2007. Ethnobotanical studies of plants of Mianwali district Punjab, Pakistan. Pak. J. Bot 39, 2285-2290.

52. Reuter, M.A., Hudson, C., Van Schaik, A., Heiskanen, K., Meskers, C., Hagelüken, C., 2013. UNEP, Environmental risk and challenges and anthropogenic metals flow and cycles: A Report of the Working Group on the Global Metal Flows to the International Resource Panel. 231.

53. Safari, M., Ramavandi, B., Sanati, A.M., Sorial, G.A., Hashemi, S., Tahmasebi, S., 2018. Potential of tree leaf/bark to control atmospheric metals in a gas and petrochemical zone. Journal of environmental management 222, 12-20.

54. Sajjad, K., Farooq, R., Shahbaz, S., Khan, M.A., Sadique, M., 2009. Health risk assessment of heavy metals for population via consumption of vegetables. World Applied Science Journal 6, 1602-1606.

55. Sakizadeh, M., Mirzaei, R., Ghorbani, H., 2016. Accumulation and soil-to-plant transfer factor of lead and manganese in some plant species in Semnan province, central Iran. Iranian Journal of Toxicology 10, 29-33.

56. Salazar, M.J., Rodriguez, J.H., Nieto, G.L., Pignata, M.L., 2012. Effects of heavy metal concentrations (Cd, Zn and Pb) in agricultural soils near different emission sources on quality, accumulation and food safety in soybean [Glycine max (L.) Merrill]. Journal of hazardous materials, 233, 244-253.

57. Schweinzer, V., Iwersen, M., Drillich, M., Wittek, T., Tichy, A., Mueller, A., KrametterFroetscher, R., 2017. Macromineral and trace element supply in sheep and goats in Austria. Veterin. Medici 62, 62-73.

58. Shad, H.A., Khan, Z.I., Ahmad, K., Rizwan, Y., Tahir, H.M., 2014. Human health hazards caused by heavy metals accumulation in wheat Variety "Sehar2006" irrigated with domestic sewage water. Biologia (Pakistan) 60, 99-102.

59. Sharma, P., Dubey, R.S., 2005. Lead toxicity in plants. Brazilian journal of plant physiology 17, 35-52.

60. Siddique, S., Ahmad, K., Khan, Z.I., Wajid, K., Bashir, H., Munir, M., Nadeem, M., Noorka, I.R., Malik, I.S., Ashfaq, A., Ugulu, I., Akhtar, M., Akhtar, P., Mehmood, N., Muqadas, H., Shehzadi, M., 2019. Sodium status of soil, forages, and small ruminants of Punjab, Pakistan. Pure and Applied Biology (PAB) 8, 1950-1961.

61. Simonsen, L.O., Harbak, H., Bennekou, P., 2012. Cobalt metabolism and toxicology-a brief update. Science of the Total Environment $432,210-215$.

62. Singh, A., Sharma, R.K., Agrawal, M., Marshall, F.M., 2010. Health risk assessment of heavy metals via dietary intake of food stuffs from the wastewater irrigated site of a dry tropical area of India. Food and Chemical Toxicology 48, 611-619.

63. Smith, K.M., Dagleish, M.P., Abrahams, P.W., 2010. The intake of lead and associated metals by sheep grazing mining-contaminated floodplain pastures in mid-Wales, UK: II. Metal concentrations in blood and wool. Science of the total environment 408, 1035-1042.

64. Sulaiman, M.B., Salawu, K., Barambu, A.U., 2019. Assessment of Concentrations and Ecological Risk of Heavy Metals at Resident and Remediated Soils of Uncontrolled Mining Site at Dareta Village, Zamfara, Nigeria. Journal of Applied Sciences and Environmental Management 23, 187-193.

65. Swarup, D., Naresh, R., Varshney, V.P., Balagangatharathilagar, M., Kumar, P., Nandi, D., Patra, R.C., 2007. Changes in plasma hormones profile and liver function in cows naturally exposed to lead and cadmium around different industrial areas. Research in veterinary science 82, 16-21.

66. Tahir, M., Iqbal, M., Abbas, M., Tahir, M.A., Nazir, A., Iqbal, D.N., Kanwal, Q., Hassan, F., Younas, U., 2017. Comparative study of heavy metals distribution in soil, forage, blood and milk. Acta Ecologica Sinica 37, 207-212.

67. Tarhan, D., Ülgen, S., Alkan, F.A., Erdikmen, D.O., Yaramiş, Ç.P., Or, M.E., Barutçu, Ü.B., 2016. Evaluation of tear and serum trace elements (copper, selenium, and cobalt) in sheep. Turkish Journal of Veterinary and Animal Sciences 40, 34-39.

68. Ugulu, I., Ahmad, K., Khan, Z.I., Munir, M., Wajid, K., Bashir, H., 2020. Effects of organic and chemical fertilizers on the growth, heavy metal/metalloid accumulation, and human health risk of wheat (Triticum aestivum L.). Environmental Science and Pollution Research 1-13.

69. Unver, M.C., Ugulu, I., Durkan, N., Baslar, S., Dogan, Y., 2015. Heavy metal contents of Malva sylvestris sold as edible greens in the local markets of Izmir. Ekoloji 24, 13-25.

70. Uren NC .2013. Cobalt and manganese. In Heavy Metals in Soils. Springer, Dordrecht 335-366.

71. USEPA (US Environmental Protection Agency) .2002. Region 9, Preliminary Remediation Goals. Office of Research and Development, Washington, DC, USA.

72. USEPA .2013. Integrated Risk Information System (IRIS). United States Environment Protection Agency.

73. Van der Ent, A., Baker, A.J.M., Reeves, R.D., Pollard, A.J., Schat, H., 2013. Hyperaccumulators of metal and metalloid trace elements: facts and fiction. Plant Soil 362, 319-334.

74. World Health Organization .2001. The World Health Report 2001: Mental health: new understanding, new hope.

75. World Health Organization (WHO) .2000. Safety evaluation of certain food additives and contaminants. International Programme on Chemical Safety.WHO Food Additive Series 52, 1.

76. World Health Organization .1995. The World Health Report 1995: bridging the gaps. World Health Organization.

77. Wuana, R.A., Okieimen, F.E., 2011. Heavy metals in contaminated soils: a review of sources, chemistry, risks and best available strategies for remediation. Isrn Ecology.

78. Yang, S., Liang, S., Yi, L., Xu, B., Cao, J., Guo,Y., Zhou, Y., 2014. Heavy metal accumulation and phytostabilization potential of dominant plant species growing on manganese mine tailings. Frontiers of Environmental Science \& Engineering, 8, 394-404.

79. Yang, Y., Khan, Z.I., Ahmad, K., Arshad, N., Rehman, S.U., Ullah, M.F., Wajid, K., Mahpara, S., Bashir, H., Nadeem, N., Ahmad, T., Munir, M., Malik, I.S., Ashfaq, A., Ugulu, I., Ma, J., Chen, F., Ahmad, T., 2020.Does the chromium element in forages and fodders grown in contaminated pasture lands cause

Page $10 / 16$ 
toxicity in livestock: assessing the potential risk. Rev Chim 71, 397-405.

80. Zhuang, Z., Mu, H.Y., Fu, P.N., Wan, Y.N., Yu, Y., Wang, Q., Li, H.F., 2020. Accumulation of potentially toxic elements in agricultural soil and scenario analysis of cadmium inputs by fertilization: A case study in Quzhou county. Journal of Environmental Management 269, 110797.

\section{Tables}

Table 1. Metal reference value in soil

\begin{tabular}{|lll|}
\hline Metals & Reference Values $\mathbf{( m g / k g )}$ & References \\
$\mathrm{Co}$ & 5.23 & Shad et al. (2014) \\
$\mathrm{Pb}$ & 8.15 & Singh et al. (2010) \\
\hline
\end{tabular}

Table 2. Reference value of metals and metalloids in forage

\begin{tabular}{|lll|}
\hline Metals and metalloids & $\begin{array}{l}\text { Reference values } \\
\text { Standard forages }(\mathbf{m g} / \mathbf{k g})\end{array}$ & Reference values Standard Soil \\
\hline $\mathrm{Co}$ & $50 \mathrm{c}$ & $5.23 \mathrm{a}$ \\
\hline $\mathrm{Pb}$ & $3 \mathrm{c}$ & $8.15 \mathrm{~b}$ \\
\hline
\end{tabular}

Source: a Shad et al. (2014), b Singh et al. (2010), c FAO/WHO (2001)

Table 3. Oral reference dose $(\mathrm{mg} / \mathrm{kg})$ for metals

\begin{tabular}{|ll|}
\hline Metals & $\mathbf{R f D}(\mathbf{m g} / \mathbf{k g} /$ day $)$ \\
\hline $\mathrm{Co}$ & $0.043 \mathrm{~b}$ \\
$\mathrm{~Pb}$ & $0.004 \mathrm{~b}$ \\
\hline
\end{tabular}

\section{Source $b=$ USEPA (2010)}

Table 4. Analysis of variance for Cobalt and Lead in soil forages with respect to seasons.

\begin{tabular}{|llll|}
\hline & & Cobalt $(\mathrm{Co})$ & Lead $(\mathrm{Pb})$ \\
\hline Source & Df & Mean Square & Mean Square \\
\hline Season & 2 & $0.003^{\mathrm{ns}}$ & $15.432^{\star \star}$ \\
\hline Soil & 4 & $0.002^{\mathrm{ns}}$ & $1.99^{\mathrm{ns}}$ \\
\hline Season $\times$ soil & 8 & $0.006^{\mathrm{ns}}$ & $1.916^{\mathrm{ns}}$ \\
\hline
\end{tabular}

$\star \star=$ Significant and ${ }^{\mathrm{ns}}=$ non significant

Table 5. Analysis of variance for Cobalt and Lead in forages $(\mathrm{mg} / \mathrm{kg})$

\begin{tabular}{|llll|}
\hline & & Cobalt (Co) & Lead $(\mathrm{Pb})$ \\
\hline Source & $\mathrm{df}$ & Mean Square & Mean Square \\
\hline Season & 2 & $0.045^{\star \star}$ & $34.702^{\star \star \star}$ \\
\hline Soil & 4 & $0.006^{\mathrm{ns}}$ & $2.747^{\mathrm{ns}}$ \\
\hline Season $x$ soil & 8 & $0.007^{\mathrm{ns}}$ & $2.357^{\mathrm{ns}}$ \\
\hline
\end{tabular}

$\star \star \star=$ Significant, ${ }^{\star \star}=$ Significant and ${ }^{n s}=$ non- significant

Table 6. Analysis of variance for Cobalt and Lead in animal 


\begin{tabular}{|llll|}
\hline & & Cobalt (Co) & Lead $(\mathrm{Pb})$ \\
\hline Source & Df & Mean Square & Mean Square \\
\hline Season & 2 & $0.159^{\star \star \star}$ & $26.844^{\star \star \star}$ \\
\hline Source & 2 & $0.009^{\mathrm{ns}}$ & $0.522^{\mathrm{ns}}$ \\
\hline Season $\times$ Animal & 2 & $0.02^{\star}$ & $0.197^{\mathrm{ns}}$ \\
\hline Season $\times$ Source & 4 & $0.021^{\star \star}$ & $1.331^{\mathrm{ns}}$ \\
\hline Animal $\times$ Source & 4 & $0.012^{\mathrm{ns}}$ & $1.324^{\mathrm{ns}}$ \\
\hline Season $\times$ Animal $\times$ Source & 8 & $0.01^{\mathrm{ns}}$ & $0.44^{\mathrm{ns}}$ \\
\hline
\end{tabular}

$\star * *$ and $* \star *=$ Significant and ${ }^{\mathrm{ns}}=$ non- significant

Table 7. Results for BCF of Cobalt and Lead

\begin{tabular}{|lllllll|}
\hline BCF & \multicolumn{3}{l}{ Heavy metals } & \multicolumn{4}{l|}{ Lead (Pb) } \\
\cline { 2 - 8 } & \multicolumn{2}{l}{ Cobalt (Co) } & \multicolumn{5}{l|}{} \\
\hline Season & S_1 & S_2 & S_3 & S_1 & S_2 & S_3 \\
C. procera & 0.946 & 0.583 & 0.447 & 0.748 & 0.773 & 0.929 \\
\hline D. aegyptium & 0.703 & 0.617 & 0.567 & 0.854 & 0.928 & 1.152 \\
\hline P. hysterophorus & 0.716 & 0.727 & 0.557 & 0.717 & 1.067 & 0.780 \\
\hline R. dentatus & 0.705 & 0.746 & 0.588 & 0.850 & 0.989 & 0.904 \\
\hline Z. jujube & 1.106 & 0.691 & 0.600 & 0.833 & 0.862 & 1.025 \\
\hline
\end{tabular}

Table 8. Results for pollution load index (PLI) of Cobalt and Lead

\begin{tabular}{|lllllll|}
\hline Heavy metal & \multicolumn{2}{l}{ Cobalt (Co) } & \multicolumn{4}{l|}{ Lead (Pb) } \\
\hline Season & S_1 & S_2 & S_3 & S_1 & S_2 & S_3 \\
C. procera & $\mathbf{0 . 0 7 1}$ & 0.085 & 0.102 & 0.946 & 1.044 & 1.048 \\
\hline D. aegyptium & 0.087 & 0.099 & 0.085 & 0.825 & 1.038 & 0.930 \\
\hline P. hysterophorus & 0.084 & 0.084 & 0.083 & 0.904 & 1.032 & 1.044 \\
\hline R. dentate & 0.085 & 0.083 & 0.085 & 0.809 & 1.131 & 1.336 \\
\hline Z. jujube & 0.085 & 0.082 & 0.080 & 0.833 & 1.139 & 1.045 \\
\hline
\end{tabular}

Table 9. Results for (EF) of Cobalt and Lead

\begin{tabular}{|lllllll|}
\hline Heavy metal & \multicolumn{2}{l}{ Cobalt (Co) } & \multicolumn{4}{l|}{ Lead (Pb) } \\
\hline Season & S_1 & S_2 & S_3 & S_1 & S_2 & S_3 \\
\hline C. procera & 0.172 & 0.106 & 0.081 & 2.033 & 2.101 & 2.523 \\
\hline D. aegyptium & 0.128 & 0.112 & 0.103 & 2.320 & 2.521 & 3.129 \\
\hline P. hysterophorus & 0.130 & 0.132 & 0.101 & 1.95 & 2.89 & 2.12 \\
\hline R. dentatus & 0.128 & 0.136 & 0.107 & 2.31 & 2.69 & 2.45 \\
\hline Z. jujube & 0.201 & 0.126 & 0.109 & 2.26 & 2.34 & 2.78 \\
\hline
\end{tabular}


Table 10. Daily intake metal (DIM) of Cobalt and Lead

\begin{tabular}{|c|c|c|c|c|c|c|c|c|c|c|c|}
\hline \multirow[t]{2}{*}{ DIM } & \multirow[b]{3}{*}{ Forage } & \multicolumn{10}{|c|}{ Heavy metals } \\
\hline & & \multicolumn{5}{|c|}{ Cobalt (Co) } & \multicolumn{5}{|c|}{ Lead $(\mathrm{Pb})$} \\
\hline animals & & $\begin{array}{l}\text { C. } \\
\text { procera }\end{array}$ & $\begin{array}{l}\text { D. } \\
\text { aegyptium }\end{array}$ & $\begin{array}{l}\text { P. } \\
\text { hysterophorus }\end{array}$ & $\begin{array}{l}R \text {. } \\
\text { dentatus }\end{array}$ & jujube & $\begin{array}{l}\text { C. } \\
\text { procera }\end{array}$ & $\begin{array}{l}\text { D. } \\
\text { aegyptium }\end{array}$ & $\begin{array}{l}P . \\
\text { hysterophorus }\end{array}$ & $\begin{array}{l}R \text {. } \\
\text { dentatus }\end{array}$ & jujube \\
\hline \multirow[t]{3}{*}{ Cow } & $S_{-} 1$ & 0.00059 & 0.00054 & 0.00053 & 0.00054 & 0.00084 & 0.0098 & 0.0097 & 0.0089 & 0.0095 & 0.0096 \\
\hline & S_2 & 0.00044 & 0.00054 & 0.00054 & 0.00055 & 0.0005 & 0.0112 & 0.0133 & 0.0152 & 0.0155 & 0.0136 \\
\hline & S_3 & 0.00041 & 0.00043 & 0.00041 & 0.00044 & 0.00043 & 0.0135 & 0.0148 & 0.0113 & 0.0167 & 0.0148 \\
\hline \multirow[t]{3}{*}{ Buffalo } & $S_{-} 1$ & 0.00067 & 0.00062 & 0.00061 & 0.00061 & 0.00095 & 0.0111 & 0.0111 & 0.0102 & 0.0108 & 0.0109 \\
\hline & S_2 & 0.00049 & 0.00062 & 0.00061 & 0.00063 & 0.00057 & 0.0127 & 0.0152 & 0.0173 & 0.0176 & 0.0155 \\
\hline & S_3 & 0.00046 & 0.00048 & 0.00046 & 0.0005 & 0.00048 & 0.0153 & 0.0169 & 0.0128 & 0.019 & 0.0169 \\
\hline \multirow[t]{3}{*}{ Goat } & $S_{-} 1$ & 0.00052 & 0.00047 & 0.00046 & 0.00046 & 0.00073 & 0.0085 & 0.0085 & 0.0078 & 0.0083 & 0.0083 \\
\hline & S_2 & 0.00038 & 0.00047 & 0.00047 & 0.00048 & 0.00044 & 0.0097 & 0.0116 & 0.0132 & 0.0134 & 0.0118 \\
\hline & S_3 & 0.00035 & 0.00037 & 0.00036 & 0.00038 & 0.00037 & 0.0117 & 0.0129 & 0.0098 & 0.0145 & 0.0129 \\
\hline
\end{tabular}

Table 11. Results for (HRI) of Cobalt and Lead

\begin{tabular}{|c|c|c|c|c|c|c|c|c|c|c|c|}
\hline \multirow[t]{2}{*}{ HRI } & \multirow[b]{3}{*}{ Forage } & \multicolumn{10}{|c|}{ Heavy metals } \\
\hline & & \multicolumn{5}{|c|}{ Cobalt (Co) } & \multicolumn{5}{|c|}{ Lead $(\mathrm{Pb})$} \\
\hline animals & & $\begin{array}{l}\text { C. } \\
\text { procera }\end{array}$ & $\begin{array}{l}D . \\
\text { aegyptium }\end{array}$ & $\begin{array}{l}\text { P. } \\
\text { hysterophorus }\end{array}$ & $\begin{array}{l}R . \\
\text { dentatus }\end{array}$ & jujube & $\begin{array}{l}\text { C. } \\
\text { procera }\end{array}$ & $\begin{array}{l}\text { D. } \\
\text { aegyptium }\end{array}$ & $\begin{array}{l}\text { P. } \\
\text { hysterophorus }\end{array}$ & $\begin{array}{l}R . \\
\text { dentatus }\end{array}$ & jujube \\
\hline \multirow[t]{3}{*}{ Cow } & $S_{-} 1$ & 0.013 & 0.013 & 0.012 & 0.012 & 0.019 & 2.45 & 2.44 & 2.25 & 2.38 & 2.41 \\
\hline & S_2 & 0.01 & 0.013 & 0.013 & 0.013 & 0.012 & 2.8 & 3.34 & 3.81 & 3.88 & 3.4 \\
\hline & S_3 & 0.009 & 0.009 & 0.009 & 0.01 & 0.01 & 3.37 & 3.71 & 2.82 & 4.18 & 3.71 \\
\hline \multirow[t]{3}{*}{ Buffalo } & $S_{-} 1$ & 0.016 & 0.014 & 0.014 & 0.014 & 0.022 & 2.79 & 2.77 & 2.55 & 2.71 & 2.73 \\
\hline & S_2 & 0.012 & 0.014 & 0.014 & 0.015 & 0.013 & 3.18 & 3.79 & 4.33 & 4.4 & 3.87 \\
\hline & S_3 & 0.011 & 0.011 & 0.011 & 0.012 & 0.011 & 3.83 & 4.22 & 3.21 & 4.75 & 4.22 \\
\hline \multirow[t]{3}{*}{ Goat } & S_1 & 0.012 & 0.011 & 0.011 & 0.01 & 0.017 & 2.13 & 2.11 & 1.95 & 2.07 & 2.08 \\
\hline & S_2 & 0.009 & 0.011 & 0.01 & 0.011 & 0.01 & 2.42 & 2.89 & 3.3 & 3.36 & 2.95 \\
\hline & S_3 & 0.008 & 0.009 & 0.008 & 0.008 & 0.008 & 2.92 & 3.22 & 2.45 & 3.62 & 3.22 \\
\hline
\end{tabular}

Table 12. The mean concentration of Cobalt and Lead $(\mathrm{mg} / \mathrm{kg})$ in soil

\begin{tabular}{|lllllll|}
\hline Heavy metal & Cobalt $(\mathrm{Co})$ & \multicolumn{5}{c|}{ Lead $(\mathrm{Pb})$} \\
\hline Season & S_1 & S_2 & S_3 & S_1 & S_2 & S_3 \\
\hline Soil of forages & & & & & & \\
\hline Soil of forage $C$. procera & $0.370 \pm 0.075$ & $0.442 \pm 0.019$ & $0.532 \pm 0.110$ & $7.71 \pm 0.479$ & $8.51 \pm 0.587$ & $8.54 \pm 0.649$ \\
\hline Soil of forage $D$. aegyptium & $0.455 \pm 0.003$ & $0.520 \pm 0.061$ & $0.443 \pm 0.015$ & $6.72 \pm 0.782$ & $8.46 \pm 0.440$ & $7.58 \pm 0.321$ \\
\hline Soil of forage $P$. hysterophorus & $0.437 \pm 0.009$ & $0.440 \pm 0.056$ & $0.433 \pm 0.009$ & $7.37 \pm 1.29$ & $8.41 \pm 1.22$ & $8.51 \pm 0.673$ \\
\hline Soil of forage $R$. dentatus & $0.447 \pm 0.014$ & $0.433 \pm 0.007$ & $0.442 \pm 0.007$ & $6.60 \pm 1.22$ & $9.22 \pm 1.006$ & $10.89 \pm 0.227$ \\
\hline Soil of forage $Z$. jujube & $0.445 \pm 0.009$ & $0.427 \pm 0.014$ & $0.420 \pm 0.013$ & $6.79 \pm 1.08$ & $9.29 \pm 0.642$ & $8.52 \pm 0.371$ \\
\hline
\end{tabular}

Table 13. The mean concentration of cobalt and Lead in forages $(\mathrm{mg} / \mathrm{kg})$. 


\begin{tabular}{|lllllll|}
\hline Heavy metal & Cobalt (Co) & \multicolumn{5}{c|}{ Lead (Pb) } \\
Season & S_1 & S_2 & S_3 & S_1 & S_2 & S_3 \\
\hline Forage type & & & & & & \\
C. procera & $0.350 \pm 0.03$ & $0.258 \pm 0.03$ & $0.238 \pm 0.04$ & $5.77 \pm 0.988$ & $6.58 \pm 0.323$ & $7.93 \pm 0.16$ \\
\hline D. aegyptium & $0.320 \pm 0.08$ & $0.322 \pm 0.06$ & $0.252 \pm 0.07$ & $5.74 \pm 1.38$ & $7.85 \pm 1.27$ & $8.73 \pm 0.42$ \\
\hline P. hysterophorus & $0.313 \pm 0.02$ & $0.320 \pm 0.04$ & $0.242 \pm 0.06$ & $5.29 \pm 1.03$ & $8.97 \pm 091$ & $6.64 \pm 0.37$ \\
\hline R. dentatus & $0.315 \pm 0.05$ & $0.323 \pm 0.05$ & $0.260 \pm 0.02$ & $5.61 \pm 2.02$ & $9.12 \pm 0.51$ & $9.84 \pm 0.37$ \\
\hline Z. jujube & $0.492 \pm 0.06$ & $0.295 \pm 0.06$ & $0.252 \pm 0.04$ & $5.66 \pm 1.28$ & $8.01 \pm 0.44$ & $8.73 \pm 0.26$ \\
\hline
\end{tabular}

Table 14. The mean concentration of Cobalt and Lead in animals $(\mathrm{mg} / \mathrm{kg})$.

\begin{tabular}{|llllllll|}
\hline Heavy metal & Cobalt (Co) & \multicolumn{5}{c|}{ Lead (Pb) } \\
Season & & S_1 & S_2 & S_3 & S_1 & S_2 & S_3 \\
Source & Animal & & & & & & \\
\hline Blood & Cow & $0.409 \pm 0.029$ & $0.469 \pm 0.028$ & $0.404 \pm 0.013$ & $1.19 \pm 0.191$ & $1.48 \pm 0.228$ & $2.38 \pm 0.447$ \\
\cline { 2 - 8 } & Buffalo & $0.432 \pm 0.041$ & $0.473 \pm 0.014$ & $0.389 \pm 0.015$ & $1.25 \pm 0.226$ & $1.25 \pm 0.312$ & $2.44 \pm 0.462$ \\
\cline { 2 - 8 } & Sheep & $0.471 \pm 0.028$ & $0.536 \pm 0.026$ & $0.404 \pm 0.012$ & $1.01 \pm 0.158$ & $1.67 \pm 0.347$ & $1.60 \pm 0.335$ \\
\hline Hair & Cow & $0.537 \pm 0.047$ & $0.510 \pm 0.010$ & $0.411 \pm 0.015$ & $1.09 \pm 0.169$ & $2.20 \pm 0.432$ & $2.33 \pm 0.438$ \\
\cline { 2 - 8 } & Buffalo & $0.459 \pm 0.026$ & $0.457 \pm 0.026$ & $0.416 \pm 0.021$ & $1.00 \pm 0.199$ & $1.41 \pm 0.276$ & $2.05 \pm 0.471$ \\
\cline { 2 - 8 } Feces & Sheep & $0.472 \pm 0.030$ & $0.514 \pm 0.013$ & $0.377 \pm 0.012$ & $1.02 \pm 0.158$ & $2.32 \pm 0.453$ & $2.15 \pm 0.370$ \\
\cline { 2 - 8 } & Cow & $0.471 \pm 0.019$ & $0.518 \pm 0.011$ & $0.424 \pm 0.013$ & $0.63 \pm 0.033$ & $1.85 \pm 0.307$ & $2.08 \pm 0.319$ \\
& Buffalo & $0.482 \pm 0.023$ & $0.386 \pm 0.014$ & $0.406 \pm 0.014$ & $1.25 \pm 0.281$ & $2.02 \pm 0.331$ & $1.87 \pm 0.335$ \\
\cline { 2 - 8 } & Sheep & $0.512 \pm 0.025$ & $0.427 \pm 0.012$ & $0.383 \pm 0.015$ & $1.13 \pm 0.164$ & $2.22 \pm 0.373$ & $2.19 \pm 0.340$ \\
\hline
\end{tabular}

\section{Figures}


Season_1

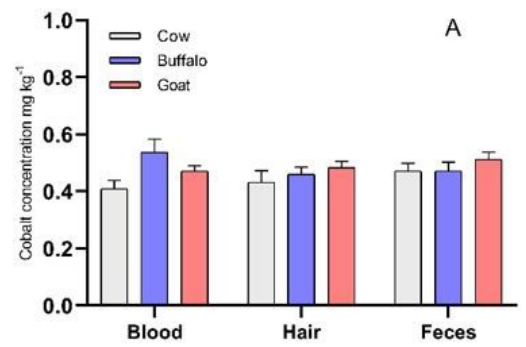

Season_2

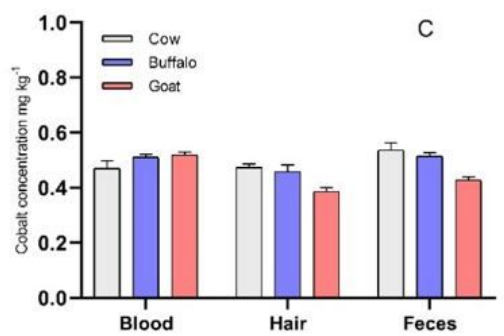

Season_3

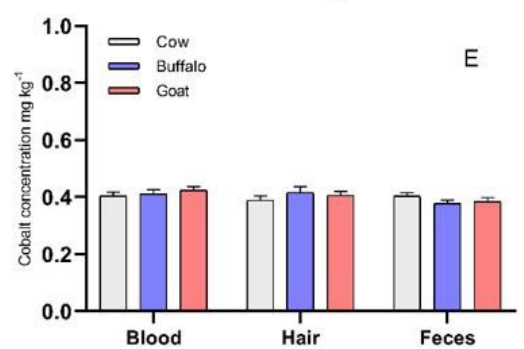

Season_1

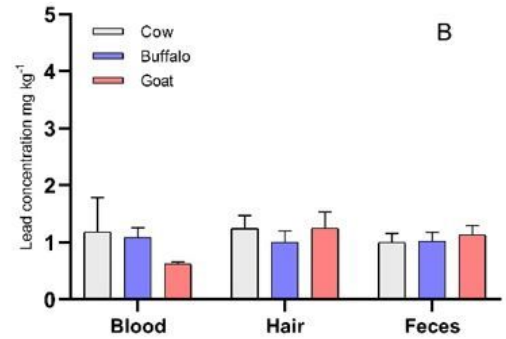

Season_2

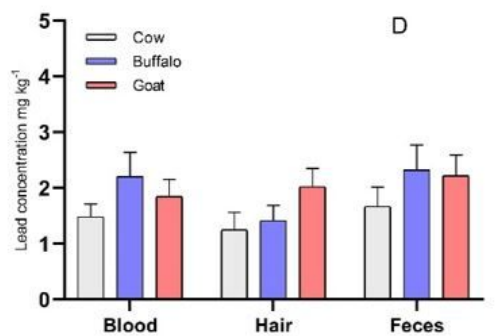

Season_3

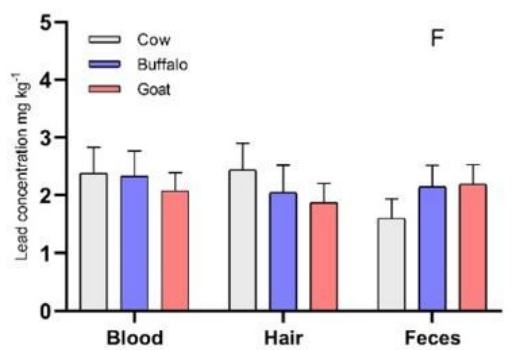

Figure 1

Mean heavy metal ions concentration in animals during different seasons
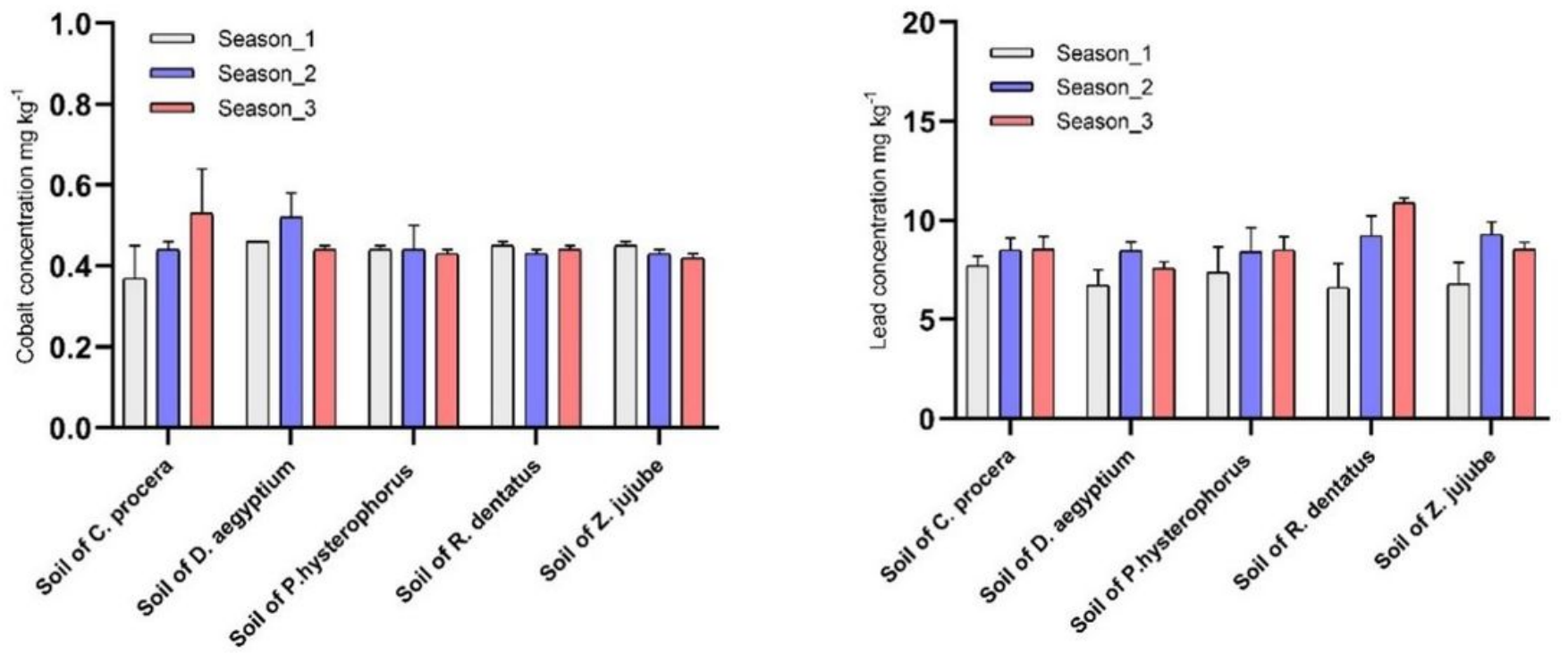
Figure 2

Mean heavy metal ions concentration in different soils of forage during different seasons
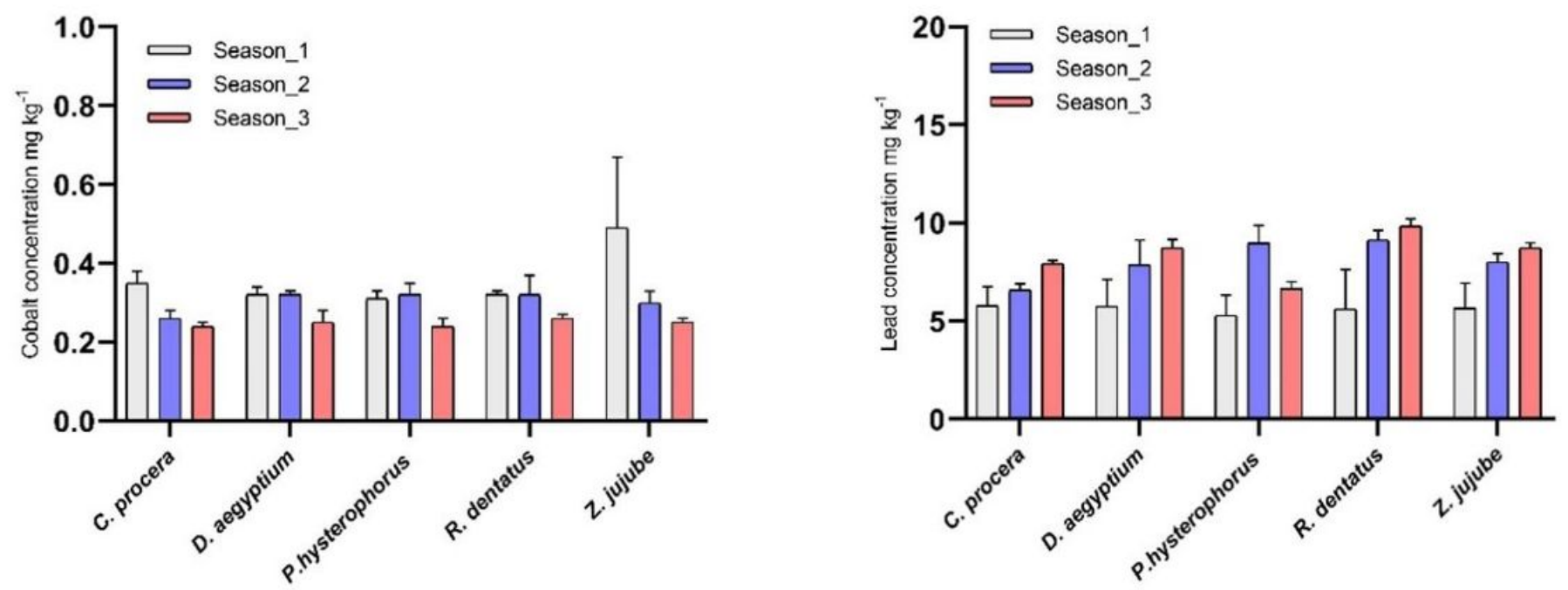

Figure 3

Mean heavy metal ions concentration in different forages during different seasons 